\title{
Bacterial Filter Device
}

National Cancer Institute

\section{Source}

National Cancer Institute. Bacterial Filter Device. NCI Thesaurus. Code C49958.

A filter designed to remove bacteria from a gas or liquid. 